\title{
Effect of Dietary RNA on Growth and Food Intake of Young Chicks
}

\author{
Yutaka Karasawa and Tooru KuBOTA \\ Laboratory of Animal Nutrition and Feed Science, \\ Faculty of Agriculture, Shinshu University, \\ Minamiminowa, Nagano-ken 399-45
}

1. Effects of an inclusion of $10 \%$ RNA into diets containing 10,20 and $30 \%$ isolated soybean protein were examined on growth, food intake and nitrogen excretion of chicks from 6 days of age for 15 days.

2. RNA additions to the three-protein-level diets resulted in appreciable decreases in food intake and in significant growth depression throughout the experiment (10 and $20 \%$ protein diets, $\mathrm{P}<0.05$ ), with no effect on food conversion efficiency.

3. RNA inclusions in the diets also decreased apparent nitrogen unilization $\{(\mathrm{N}$ intake $-\mathrm{N}$ excretion $) / \mathrm{N}$ intake $\} \quad(10$ and $30 \%$ protein diets, $\mathrm{P}<0.05)$ and increased the ratio of excreted uric acid $\mathrm{N}$ to ingested $\mathrm{N}$ (10 and $20 \%$ protein diets, $\mathrm{P}<0.05)$.

4. Kidney weight per $100 \mathrm{~g}$ of body weight was increased by dietary RNA (10 and $30 \%$ protein diets, $\mathrm{P}<0.05)$, but liver weight was unaffected.

5. Neither uric acid content in kidney nor in liver was affected by dietary RNA.

6. These results suggest that the growth depression by an inclusion of RNA into diets resulted from decreased food intake which may be caused by adverse effects of absorbed RNA-degradation products.

(Jpn. Poult. Sci., $27: 165-172,1990)$

Key words : dietary RNA, chick, growth, food intake

The high content of nucleic acids in single-cell protein such as bacteria, yeasts, fungi or algae is one of the main factors limiting the use of the protein for the nutrition of animals and humans. Dietary nucleic acids have been reported to be potent dietary components in elevating blood uric acid levels and urinary uric acid excretion in $\operatorname{man}^{1-3)}$ and Dalmatian $\operatorname{dog} \mathrm{s}^{4)}$ and in depressing food intake by the $\operatorname{dog} \mathrm{s}^{4)}$. Dietary adenine, one of purine bases of RNA (ribonucleic acid) which largely accounts for yeast nucleic acids, also adversely affects growth ${ }^{5,6)}$, food intake ${ }^{5)}$ and renal function ${ }^{6,7)}$ in rats although reutilized by salvage pathway at a low inclusion in the diet.

In birds, there are few studies on these adverse effects of dietary nucleic acids and purines, although dietary adenine causes growth depression in chicks at inclusion levels of 0.8 and $0.4 \%$ in nitrogen-limiting and nitrogen-adequate diets, respectively ${ }^{8)}$. In this study $10 \%$ RNA diet containing about $1 \%$ of adenine was fed to chicks and it was examined whether dietary RNA has adverse effects on growth and food intake of

Received Aug. 14, 1989 
chicks.

\section{Materials and Methods}

Day-old Single Comb white Leghorn (Hyline W 36) male chicks were individually housed in metabolic cages controlled at $30^{\circ} \mathrm{C}$ under 24 -hour light and fed a commercial chick starter diet for 5 days. On day 6 five chicks were allotted to each of 6 dietary groups with their initial body weight of $68.2 \mathrm{~g}$, and they had free access to an experimental diet and water for 15 days. They were weighed every 5 days and food consumed was recorded daily.

Experimental diets used in this study were $10 \%$ isolated soybean protein (ISB) (10), $10 \%$ ISB plus $10 \%$ RNA (10 R), 20\% ISB (20), 20\% ISB plus $10 \%$ RNA (20 R), 30\% ISB (30) and $30 \%$ ISB plus 10\% RNA (30 R) diets, which respectively contained 10.2, 20.1, 20.3, 30.2, 30.5 and 40.4\% crude protein, and 3.6, 3.6, 3.6, 3.5, 3.5 and $3.5 \mathrm{kcal} \mathrm{ME} \mathrm{per}$ gram. The composition of these diets is shown in Table 1. RNA extracted from Candida utilis (purity 86.84\%, Kohjin Co. Ltd, Tokyo, Japan) was added at the expense of cornstarch. This RNA contained $10.4 \%$ adenine (calculated value).

For the last 3 days of the 15-day feeding period total excreta was daily collected and dried in an electric oven with forced aeration at $55^{\circ} \mathrm{C}$ after presprayed with $5 \mathrm{~N}$ $\mathrm{HCl}$. At the end of the experiment the chicks were killed by exsanguination. The liver and kidney were excised immediately, weighed and stored in a freezer at $-25^{\circ} \mathrm{C}$ until analyzed. Total nitrogen in the dried excreta was determined by a Kjeldahl

Table 1. Composition of experimental diets (\%)

\begin{tabular}{|c|c|c|c|c|c|c|}
\hline & \multicolumn{6}{|c|}{ Diet } \\
\hline & 10 & $10 \mathrm{R}$ & 20 & $20 \mathrm{R}$ & 30 & $30 \mathrm{R}$ \\
\hline Cornstarch & 100 & 100 & 100 & 100 & 100 & 100 \\
\hline Soybean meal ${ }^{11}$ & 11.77 & 11.77 & 23.53 & 23.53 & 35.30 & 35.30 \\
\hline Corn oil & 15.00 & 15.00 & 15.00 & 15.00 & 15.00 & 15.00 \\
\hline Cellulose powder ${ }^{2)}$ & 3.00 & 3.00 & 3.00 & 3.00 & 3.00 & 3.00 \\
\hline Mienral $\operatorname{mix}^{21}$ & 5.36 & 5.36 & 5.36 & 5.36 & 5.36 & 5.36 \\
\hline $\mathrm{NaHCO}_{3}$ & 1.00 & 1.00 & 1.00 & 1.00 & 1.00 & 1.00 \\
\hline Choline chloride & 0.20 & 0.20 & 0.20 & 0.20 & 0.20 & 0.20 \\
\hline Glycine & 0.13 & 0.13 & 0.26 & 0.26 & 0.39 & 0.39 \\
\hline Methionine & 0.04 & 0.04 & 0.07 & 0.07 & 0.11 & 0.11 \\
\hline Vitamin $\operatorname{mix}^{31}$ & 0.06 & 0.06 & 0.06 & 0.06 & 0.06 & 0.06 \\
\hline$\alpha$-Tocopherol acetate & 0.002 & 0.002 & 0.002 & 0.002 & 0.002 & 0.002 \\
\hline Antioxidant & 0.0125 & 0.0125 & 0.0125 & 0.0125 & 0.0125 & 0.0125 \\
\hline RNA & 0 & 11.52 & 0 & 11.52 & 0 & 11.52 \\
\hline $\mathrm{CP}$ & 10.2 & 20.1 & 20.3 & 30.2 & 30.5 & 40.4 \\
\hline $\mathrm{ME}(\mathrm{kcal} / \mathrm{g})$ & 3.6 & 3.6 & 3.6 & 3.5 & 3.5 & 3.5 \\
\hline
\end{tabular}

1) Fujipro-R (CP 85\%, Fuji Oil Co., Ltd., Osaka, Japan).

2) HP 310 (Kojin Co., Ltd., Tokyo, Japan).

3) Velu et al, J. Nutr. $101: 1249$ (1971).

4) Butyl hydroxy toluene.

5) Ribonucleic acid, sodium salt (purity 86.84\%, Kojin Co., Ltd., Tokyo, Japan). 
method and uric acid in the excreta by the enzymatic spectrophotometric method ${ }^{9)}$. Liver and kidney uric acid contents were determined by the method of DuBBs et al. ${ }^{10)}$ after the organs were processed as reported by KARASAwA ${ }^{11}$. The gross energy values of the experimental diets and the excreta were determined using a bomb calorimeter (Shimadzu Co. Ltd, Kyoto, Japan).

The significance levels of differences between means were determined with Student's $t$-test ${ }^{12)}$.

\section{Results}

Changes in body weight of chickens fed RNA-containing diets with time are shown in Fig. 1. All RNA additions to 10, 20 and 30\% protein diets depressed growth as compared with corresponding control diets during the 15-day experimental period; especially the depression was large and significant on days 10 and 15 in $20 \%$ protein group and on day 10 in $10 \%$ protein group $(\mathrm{P}<0.05)$.

Time courses in daily food intake by chickens fed RNA-containing diets are shown in Fig. 2. Chickens fed 20 and $30 \%$ protein control diets with no RNA ate almost the same levels of daily food during the experimental period, which were the highest levels in all dietary groups. An addition of RNA to the 30\% protein diet decreased food

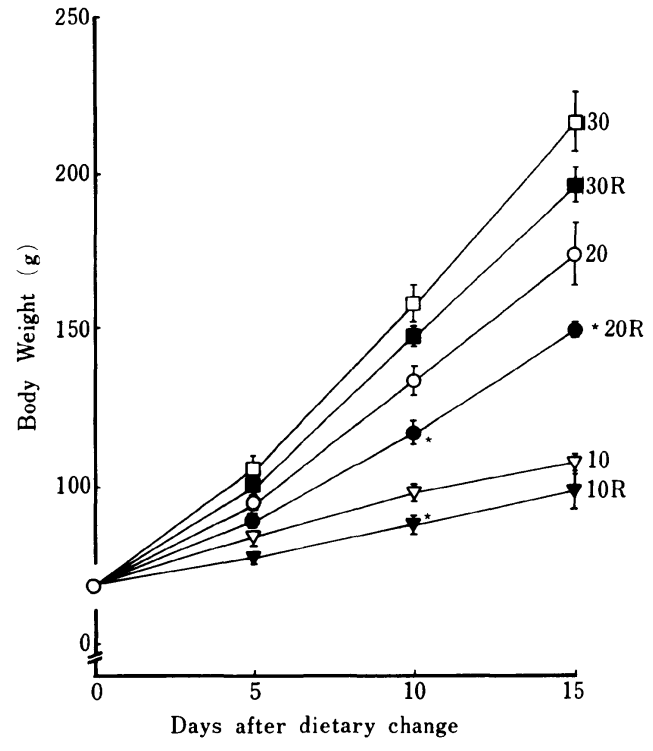

Fig. 1. Effect of dietary RNA on growth of the chicken. Each point with vertical bar indicates mean \pm SEM of 5 chicks. Points having the different superscript differ significantly $(\mathrm{P}<$ $0.05)$. $10: 10 \%$ ISB diet, $10 \mathrm{R}: 10 \%$ ISB $+10 \%$ RNA diet, $20: 20 \%$ ISB diet, $20 \mathrm{R}: 20 \%$ ISB $+10 \%$ RNA diet, $30: 30 \%$ ISB diet, $30 \mathrm{R}: 30 \%$ ISB $+10 \%$ RNA diet.

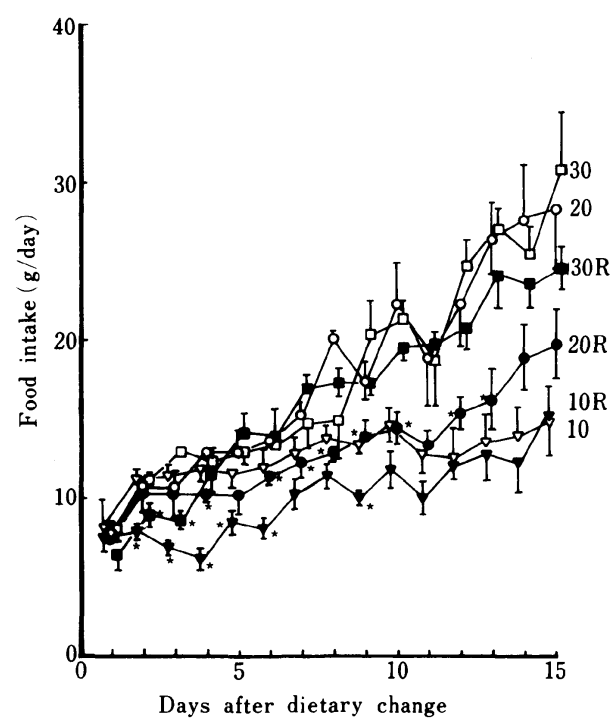

Fig. 2. Effect of dietary RNA on daily food intake of the chicken. Each point with vertical bar indicates mean \pm SEM of 5 chicks. *Significantly different from the value for corresponding control groups $(\mathrm{P}<0.05)$. Other explanations are given in the legend for Fig. 1. 
intake for the first 3 days (days 2 and $3, \mathrm{P}<0.05$ ) and for the last 4 days, but not during the period day 4 to 11 . The addition of RNA to the $20 \%$ protein diet resulted in decreases in daily food intake after day $3(\mathrm{P}<0.05$ except days $5,11,14$ and 15), which became larger with time. The food intake by chickens fed a $10 \%$ protein diet with no RNA showed almost the same increasing pattern and level as food consumption by those fed 20 and $30 \%$ protein diets without RNA up to day 7 , but thereafter the increasing rate of food intake with time was very low in the former ; the final daily food intake was $14.8 \pm 2.2 \mathrm{~g}$ and $31.0 \pm 3.6 \mathrm{~g}$ in chickens fed 10 and $30 \%$ protein control diets, respectively. Chickens fed a RNA-supplemented $10 \%$ protein diet ate a smaller amount of food than corresponding control chickens except the last day of experiment, especially for the first 6 days $(\mathrm{P}<0.05$, day 2 to 6$)$.

Table 2 shows total food intake, weight gain and food conversion efficiency during the 15-day experimental period. Total food intake was significantly decreased by RNA additions to 10 and $20 \%$ protein diets $(\mathrm{P}<0.05)$, and such a tendency was also found in $30 \%$ protein-fed chickens. In parallel with food intake, body weight gain during the period tended to be depressed by dietary RNA at all the protein levels $(20 \%$ protein diet, $\mathrm{P}<0.05)$. However, there was no difference in food conversion efficiency (body weight gain/food intake) between control and RNA-added diet groups (10 vs. $10 \mathrm{R} ; 20$ vs. $20 \mathrm{R}$; 30 vs. $30 \mathrm{R}$ ), although it was significantly affected by dietary protein levels $(\mathrm{P}<0.05)$.

Table 3 presents nitrogen intake and excretion, uric acid excretion, excretory uric acid $\mathrm{N}$ : intake $\mathrm{N}$ ratio and $\mathrm{N}$ utilization in chickens fed RNA-added and control diets for the last 3 days of the experimental period. In spite of a decrease in food intake, the chickens fed RNA-added diets ingested total $\mathrm{N}$ equal to or more than that of corresponding control chickens because of high content of $\mathrm{N}$ in RNA diets compared with each control diet $(10 \mathrm{R}>10, \mathrm{P}<0.05)$. Total $\mathrm{N}$ excretion and uric acid $\mathrm{N}$ excretion were also larger in amount in chickens fed RNA-added diets than in correspnding control chickens at all dietary protein levels $(\mathrm{P}<0.05$, except total $\mathrm{N}$ excretion for $20 \%$ protein diet). The ratio of excretory uric acid- $\mathrm{N}$ to intake $\mathrm{N}$ was increased by additions of RNA to diets (diets 10 and 20, $\mathrm{P}<0.05$ ). Nitrogen utilization tended to decrease when RNA was added to 10,20 and $30 \%$ protein diets.

Table 2. Effect of dietary RNA on food intake, growth and food efficiency

\begin{tabular}{lcccccc}
\hline \hline & \multicolumn{7}{c}{ Diet } \\
\cline { 2 - 7 } & 10 & $10 \mathrm{R}$ & 20 & $20 \mathrm{R}$ & 30 & $30 \mathrm{R}$ \\
\hline Food intake 1 ) & 188.4 & 150.0 & 268.5 & 198.0 & 270.4 & 249.2 \\
(g/chick/15 days) & $\pm 10.2 \mathrm{a}$ & $\pm 7.7 \mathrm{c}$ & $\pm 17.6 \mathrm{~b}$ & $\pm 7.1 \mathrm{a}$ & $\pm 13.6 \mathrm{~b}$ & $\pm 10.2 \mathrm{~b}$ \\
Body weight gain ${ }^{11}$ & 38.6 & 29.0 & 105.8 & 81.3 & 147.2 & 127.4 \\
(g/chick/15 days) & $\pm 3.2 \mathrm{a}$ & $\pm 3.2 \mathrm{a}$ & $\pm 8.6 \mathrm{~b}$ & $\pm 1.7 \mathrm{~d}$ & $\pm 10.1 \mathrm{c}$ & $\pm 6.3 \mathrm{c}$ \\
FE $^{2)}$ & 0.20 & 0.19 & 0.39 & 0.41 & 0.54 & 0.51 \\
& $\pm 0.01 \mathrm{a}$ & $\pm 0.03 \mathrm{a}$ & $\pm 0.01 \mathrm{~b}$ & $\pm 0.02 \mathrm{~b}$ & $\pm 0.03 \mathrm{c}$ & $\pm 0.04 \mathrm{c}$ \\
\hline
\end{tabular}

Values are means \pm SEM of 5 chicks.

Means having the different superscript differ significantly $(P<0.05)$.

1) During a 15-day experimental period

2) Food efficiency : body weight gain/food intake. 
Table 3. Effect of dietary RNA on nitrogen intake and excretion, uric acid (UA) excretion, $\mathrm{UA}-\mathrm{N}$ : intake $\mathrm{N}$ ratio and $\mathrm{N}$ utilization

\begin{tabular}{|c|c|c|c|c|c|c|}
\hline & \multicolumn{6}{|c|}{ Diet } \\
\hline & 10 & $10 \mathrm{R}$ & 20 & $20 \mathrm{R}$ & 30 & $30 \mathrm{R}$ \\
\hline $\begin{array}{l}\text { Total N intake }{ }^{1)} \\
\text { (g/chick/3 days) }\end{array}$ & $\begin{array}{l}0.69 \\
\pm 0.69 \mathrm{a}\end{array}$ & $\begin{aligned} & 1.29 \\
\pm & 0.17 \mathrm{~b}\end{aligned}$ & $\begin{array}{l}2.69 \\
\pm 0.31 \mathrm{c}\end{array}$ & $\begin{array}{l}2.66 \\
\pm 0.22 \mathrm{c}\end{array}$ & $\begin{aligned} & 4.08 \\
\pm & 0.30 \mathrm{c}\end{aligned}$ & $\begin{aligned} & 4.68 \\
\pm & 0.30 \mathrm{~d}\end{aligned}$ \\
\hline RNA intake ${ }^{1)}$ & 0 & $\begin{array}{l}0.63 \\
\pm 0.09 \mathrm{a}\end{array}$ & 0 & $\begin{array}{l}0.87 \\
\pm 0.07 \mathrm{ab}\end{array}$ & 0 & $\begin{aligned} & 1.11 \\
\pm & 0.08 \mathrm{~b}\end{aligned}$ \\
\hline $\mathrm{N}$ excretion ${ }^{11}$ & $\begin{array}{l}0.30 \\
\pm 0.03 \mathrm{a}\end{array}$ & $\begin{aligned} & 0.73 \\
\pm & 0.11 \mathrm{~b}\end{aligned}$ & $\begin{array}{l}0.95 \\
\pm 0.08 \mathrm{bc}\end{array}$ & $\begin{array}{l}1.21 \\
\pm 0.13 \mathrm{c}\end{array}$ & $\begin{array}{l}1.78 \\
\pm 0.17 \mathrm{~d}\end{array}$ & $\begin{aligned} & 2.94 \\
\pm & 0.24 \mathrm{e}\end{aligned}$ \\
\hline UA-N excretion ${ }^{11}$ & $\begin{array}{l}0.07 \\
\pm 0.01 \mathrm{a}\end{array}$ & $\begin{aligned} & 0.23 \\
\pm & 0.02 \mathrm{~b}\end{aligned}$ & 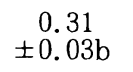 & $\begin{array}{c}0.52 \\
\pm 0.04 \mathrm{c}\end{array}$ & $\begin{array}{l}0.71 \\
\pm 0.07 \mathrm{c}\end{array}$ & $\begin{array}{l}1.09 \\
\pm 0.07 \mathrm{~d}\end{array}$ \\
\hline $\mathrm{UA}-\mathrm{N}$ /intake $\mathrm{N}$ & $\begin{array}{l}0.10 \\
\pm 0.01 \mathrm{a}\end{array}$ & $\begin{aligned} & 0.19 \\
\pm & 0.03 \mathrm{bc}\end{aligned}$ & $\begin{array}{l}0.11 \\
\pm 0.01 \mathrm{ab}\end{array}$ & $\begin{aligned} & 0.19 \\
\pm & 0.01 \mathrm{c}\end{aligned}$ & $\begin{aligned} & 0.18 \\
\pm & 0.02 \mathrm{bc}\end{aligned}$ & $\begin{array}{l}0.23 \\
\pm 0.01 \mathrm{bc}\end{array}$ \\
\hline $\mathrm{N}$ utilization ${ }^{2)}$ & 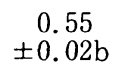 & $\begin{array}{ll} & 0.39 \\
\pm & 0.09 \mathrm{a}\end{array}$ & 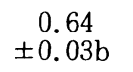 & $\begin{aligned} & 0.54 \\
\pm & 0.02 \mathrm{~b}\end{aligned}$ & $\begin{array}{l}0.54 \\
\pm 0.07 \mathrm{~b}\end{array}$ & $\begin{array}{l}0.37 \\
\pm 0.02 \mathrm{a}\end{array}$ \\
\hline
\end{tabular}

Values are means \pm SEM of 5 chicks.

Means having the different superscript differ significantly $(P<0.05)$.

1) Recorded for the last 3 days of a 15-day experimental period.

2) ( $\mathrm{N}$ intake $-\mathrm{N}$ excretion) $/ \mathrm{N}$ intake.

Table 4. Effect of dietary RNA on liver and kidney weights and their uric acid contents

\begin{tabular}{lcccccc}
\hline \hline & \multicolumn{7}{c}{ Diet } \\
\cline { 2 - 6 } & 10 & $10 \mathrm{R}$ & 20 & $20 \mathrm{R}$ & 30 & $30 \mathrm{R}$ \\
\hline Liver weight & 3.56 & 3.16 & 2.83 & 2.95 & 3.02 & 3.32 \\
(g/100 g BW) & $\pm 0.15 \mathrm{a}$ & $\pm 0.13 \mathrm{ab}$ & $\pm 0.09 \mathrm{~b}$ & $\pm 0.15 \mathrm{bc}$ & $\pm 0.09 \mathrm{bc}$ & $\pm 0.12 \mathrm{ac}$ \\
Kidney weight & 1.34 & 1.66 & 1.35 & 1.48 & 1.42 & 1.72 \\
(g/100 g BW) & $\pm 0.05 \mathrm{a}$ & $\pm 0.07 \mathrm{bc}$ & $\pm 0.14 \mathrm{ac}$ & $\pm 0.05 \mathrm{ac}$ & $\pm 0.04 \mathrm{a}$ & $\pm 0.07 \mathrm{~b}$ \\
Hepatic uric acid & 0.09 & 0.15 & 0.24 & 0.25 & 0.25 & 0.25 \\
(mg/g wet wt.) & $\pm 0.03 \mathrm{a}$ & $\pm 0.04 \mathrm{ab}$ & $\pm 0.08 \mathrm{ab}$ & $\pm 0.01 \mathrm{~b}$ & $\pm 0.05 \mathrm{~b}$ & $\pm 0.07 \mathrm{ab}$ \\
Renal uric acid & 0.14 & 0.31 & 0.17 & 0.20 & 0.17 & 0.11 \\
(mg/g wet wt.) & $\pm 0.05 \mathrm{a}$ & $\pm 0.01 \mathrm{a}$ & $\pm 0.06 \mathrm{a}$ & $\pm 0.06 \mathrm{a}$ & $\pm 0.06 \mathrm{a}$ & $\pm 0.05 \mathrm{a}$ \\
\hline
\end{tabular}

Values are means \pm SEM of 5 chicks.

Means having the different superscript differ significantly $(P<0.05)$.

Effects of dietary RNA on liver and kidney weights and their uric acid contents are shown in Table 4. Dietary RNA unaffected liver weight but significantly increased kidney weight (diets 10 and $30, \mathrm{P}<0.05$ ). Hepatic and renal uric acid contents tended to increase when RNA was added to a $10 \%$ protein diet, but not in additions of RNA to 20 and $30 \%$ protein diets.

\section{Discussion}

It has been reported that single-cell proteins are potential sources of protein for the nutrition of animals and man, but decrease food intake by $\operatorname{dogs}{ }^{4)}$ and chicks ${ }^{13-15)}$ and growth of chicks ${ }^{13-15)}$ when replaced all dietary protein. PlavniK et al. ${ }^{16)}$ have also observed the reduced consumption of bacteria protein-containing diet and growth depression with young chicks and concluded that the reduced food intake is not due to a petroleum-ether-soluble factor, nor to the high and low concentrations of sodium and 
potassium, respectively, in bacteria protein preparation. RNA, which accounts for $5.0-8.0 \%$ of bacteria and $2.0-4.0 \%$ of yeast on dry matter basis ${ }^{17)}$, has been found to depress food intake by $\operatorname{dogs}^{4}$. In the present experiment RNA additions to 10,20 and $30 \%$ protein diets also resulted in appreciable decreases in food intake and in significant growth depression throughout the experiment. The adverse effects of single-cell protein on food intake and growth of chickens, therefore, may be due to nucleic acids in the single-cell protein. However, further studies should be done to establish this, since the additional level of dietary RNA in the present experiment was much higher than the content of RNA in the dietary single-cell protein causing the adverse effects in previous studies.

The chicken growth depression can be explained completely in the case of bacteria protein or almost completely in that of yeast protein on the basis of reduced food intake, without a decided effect on food utilization ${ }^{16)}$. No difference in growth has been reported among chickens fed diets with 0,15 or $30 \%$ yeast when food intake was reduced to $90 \%$ of that consumed by the $30 \%$ yeast group fed ad libitum ${ }^{13)}$. The growth depression of chickens fed RNA-containing diets in the present experiment was accompanied by reduced food intake, with no effect on food efficiency over a 15-day period. This indicates that the reduced performance associated with dietary RNA may mainly due to the reduction of food intake by adding RNA to diets.

It is possible that the reduced food intake is caused as a result of effect of dietary RNA on nitrogen metabolism. Dietary adenine, one of purines in RNA, is known to reduce food intake by rats $^{5)}$ and weight gain of rats $^{5,7)}$ and $\operatorname{chicks}^{8)}$, to accumulate a toxic metabolite of adenine and to increase plasma urea levels due to kidney incapacitation $^{5,6)}$ and kidney weight ${ }^{7)}$. Elevated blood uric acid levels in humans are also reported to be associated with dietary nucleic acids ${ }^{1,2}$. RNA-added diets containing about $1 \%$ adenine in the present experiment caused increases in kidney weight as compared with corresponding control diets, but had no appreciable effect on hepatic and renal uric acid contents. The different responses of tissue uric acid contents to dietary nucleic acids between mammals and birds may be due to the fact that the latter is uricotelic.

The present experiment indicated more active synthesis of uric acid in chickens fed RNA-containing diets than in those fed control diets without RNA. RNA included in yeast protein is digestible by $77.2 \%$ in chicks ${ }^{18}$, and adenine seems to be absorbed from

chicken intestine since $94 \%$ of orally administered adenine was recovered in rat urine ${ }^{19}$. Thus the increased uric acid which appeared in excreta when dietary RNA was fed to chicks is likely to be derived from the preformed purines absorbed from the intestines. The chicken is little known about the absorption of purines in dietary RNA from the intestines and about their metabolism in the body. Further studies are needed to clarify these points.

\section{Acknowledgement}

This study was supported in part by the Misuzu-Matsuko Scientific Grant. 


\section{References}

1) Waslien, G.I., D.H. Calloway and S. Margen (1968) Uric acid production of men fed graded amounts of egg protein and yeast nucleic acid. Am. J. Clin. Nutr. 21 : 892-897.

2) Edodien, J.C., U.U. Udo, V.R. Young and N.S. Scrimshow (1970) Effects of high levels of yeast feeding on uric acid metabolism of young men. Nature, 228: 180.

3) Nuget, C.A. (1965) Renal urate excretion in gout studied by feeding ribonucleic acid. Arthritis Rheum. 8: 671-685.

4) Giesecke, D,, S. Gaebler and W. Tiemeyer (1982) Purine availability and metabolism in dogs fed single-cell protein or RNA. J. Nutr. 112 : 1822-1826.

5) Clifford, A.J. and D.L. Story (1976) Levels of purine in foods and their metabolic effects in rats. J. Nutr. $106: 435-442$.

6) Philips, F.S., J.B. Thiersch and A. Bendich (1952) Adenine intoxication in relation to in vivo formation and deposition of 2,8-dioxy-adenine in renal tubules. $\mathrm{J}$. Pharm. Exp. Therap. 104 : 20-30.

7) Story, D.L., R.E. Shrader, L.L. Theriault, D.L. Lumijarvi, T.S. Shenoy, D.A. Savaiano, R.H. Shaffer, C.Y. Ho and A.J. Clifford (1977) Effects of dietary protein, adenine and allopurinol on growth and metabolism of rats. J. Nutr. 107 : 1044-1052.

8) BAKER, D.H. and B.A. Molitoris (1974) Utilization of nitrogen from selected purines and pyrimidines and from urea by the young chick. J. Nutr. 104 : 553-557.

9) McNabB, F.M. and R.A. McNabB (1975) Proportions of ammonia, urea, urate and total nitrogen in avian urine and quantitative methods for their analysis on a single urine sample. Poult. Sci. 54 : 1498-1505.

10) Dubbs, D.A., F.W. Davis and W.S. Adams (1956) Simple microdetermination of uric acid. J. Biol. Chem. $218:$ 497-504.

11) KaRASAwa, Y. (1978) Time course changes in concentrations of nitrogenous compounds in blood and urine after methionine sulfoximine treatment in chickens fed high protein diet. Jpn. J. Zootech. Sci. 49: 450-457.

12) Snedecor, G.W. and W.G. Cochran (1967) Statistical Methods, Iowa State University Press, Ames. IA.

13) Waldroup, P.W., D.M. Hillarld and R.J. Mitchell (1971) The nutritive value of yeast grown on hydrocarbon fraction for broiler chicks. Poult. Sci., 50 : 1022-1029.

14) Shannon, D.W.F. and J.M. McNAB (1972) The effect of different dietary levels of a $n$-paraffin-grown yeast on the growth and food intake of broiler chicks. Br. Poult. Sci., 13 : 267-272.

15) D'Mello, J.P.F. and T. Acamovic (1976) Evaluation of methanol-grown bacteria as a source of protein and energy for young chicks. Br. Poult. Sci., $17: 393-401$.

16) Plavnik, I., S. Bornstein and S. Hurwitz (1981) Evaluation of methanol-grown bacteria and hydrocarbon-grown yeast as sources of protein for poultry: Studies with young chicks. Br. Poult. Sci. 22 : 123-140.

17) Giesecke, D. and W. Tiemeyer (1982) Availability and metabolism of purines of single-cell proteins in monogastric animals. Proc. Nutr. Soc. $41: 319-327$.

18) Shannon, D.W.F. and J.M. MCNAB (1973) The digestibility of the nitrogen, amino acids, lipid, carbohydrates, ribonucleic acid and phosphorus of an $n$-paraffin-grown yeast when given to colostomised laying hens. J. Sci. Fd Agric. 24 : 27-34.

19) Savaiano, D.A., C.Y. Ho, V. Chu and A.J. Clifford (1980) Metabolism of orally and intravenously aministered purines in rats. J. Nutr. 110 : 1793-1804. 


\title{
飼料中の RNA がヒナの成長と飼料摂取量に及ぼす影響
}

\author{
唐 澤豊・久保田徹 \\ 信州大学農学部 長野県南箕輪村 399-45
}

1. $10 ， 20$ および $30 \%$ 大豆粕タンパク質飼料に $10 \%$ 添加した RNA が, 6 日龄のヒナの成長, 飼料捸取量 及び窒素排泄量に及ぼす影響を 15 日間にわたって調べ た。

2. RNA の添加によって成長と飼料摂取量の低下が 認められた。しかし飼料効率には影響がみられなかった。

3. 飼料に添加した RNA は窒素利用率の低下と排 泄尿酸窒素 : 攝取窒素比の増加を招いた。

4. 体重当たりの腎重量は飼料への RNA 添加によ
って増加したが，肝重量は影響されなかった。

5. 腎の尿酸濃度も肝の尿酸濃度も飼料中の RNA による影響を受けなかった。

6. これらの結果から，飼料に添加した RNA によ る成長の遅滞は, 飼料摂取量の低下によるもので, この 低下は吸収された RNA 分解物の有害な作用による可 能性が考えられた。

（家离会誌，27：165～172，1990） キーワード : 飼料の RNA, ヒナ, 成長, 飼料捸取量 